\title{
$\mathrm{Ni}_{\mathrm{x}} \mathrm{Co}_{\mathrm{y}}$ Nanocatalyst Supported by $\mathrm{ZrO}_{2}$ Hollow Sphere for Dry Reforming of Methane: Synergetic Catalysis by Ni and Co in Alloy
}

\author{
Kefa Sheng ${ }^{1}$, Dong Luan ${ }^{2}$, Hong Jiang ${ }^{2 *}$, Fang Zeng ${ }^{1}$, Bo Wei ${ }^{1}$, Fei Pang ${ }^{1}$, Jianping Ge ${ }^{1 *}$
}

1. Shanghai Key Laboratory of Green Chemistry and Chemical Processes, School of Chemistry and Molecular Engineering, East China Normal University, Shanghai, China, 200062.

2. Beijing National Laboratory for Molecular Sciences, College of Chemistry and Molecular Engineering, Peking University, Beijing 100871, China E-mail: jpge@chem.ecnu.edu.cn; jianghchem@pku.edu.cn

Content

1. $\mathrm{N}_{2}$-adsorption-desorption isotherms .1

2. Effect of reaction temperature on the initial catalytic activity. . .2

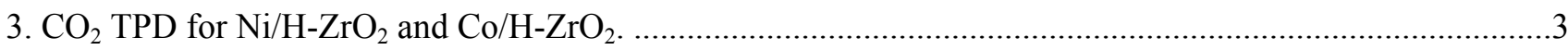

4. $\mathrm{XRD}$ patterns of $\mathrm{Ni} / \mathrm{H}-\mathrm{ZrO}_{2}$ and $\mathrm{Co} / \mathrm{H}-\mathrm{ZrO}_{2}$ after reaction for 24 hours.................................................

5. TEM images of $\mathrm{Ni} / \mathrm{H}-\mathrm{ZrO}_{2}$ and $\mathrm{Ni}_{0.8} \mathrm{Co}_{0.2} / \mathrm{H}-\mathrm{ZrO}_{2}$ catalysts after reaction for 80 hours..............................5

6. Atom concentration of the $\mathrm{Ni}_{0.8} \mathrm{Co}_{0.2} / \mathrm{H}-\mathrm{ZrO}_{2}$ catalyst from EDS analysis. ..............................................

7. Comparison of TOF values of $\mathrm{CH}_{4}$ and $\mathrm{CO}_{2}$ catalyzed by Ni-based catalysts in literature and this work. .....6

8. Comparison of $\mathrm{CH}_{4}$ and $\mathrm{CO}_{2}$ dissociative adsorption on pure and Co-doped $\mathrm{Ni}(111)$ surface based on firstprinciples computation

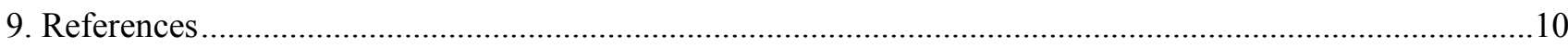


1. $\mathbf{N}_{2}$-adsorption-desorption isotherms

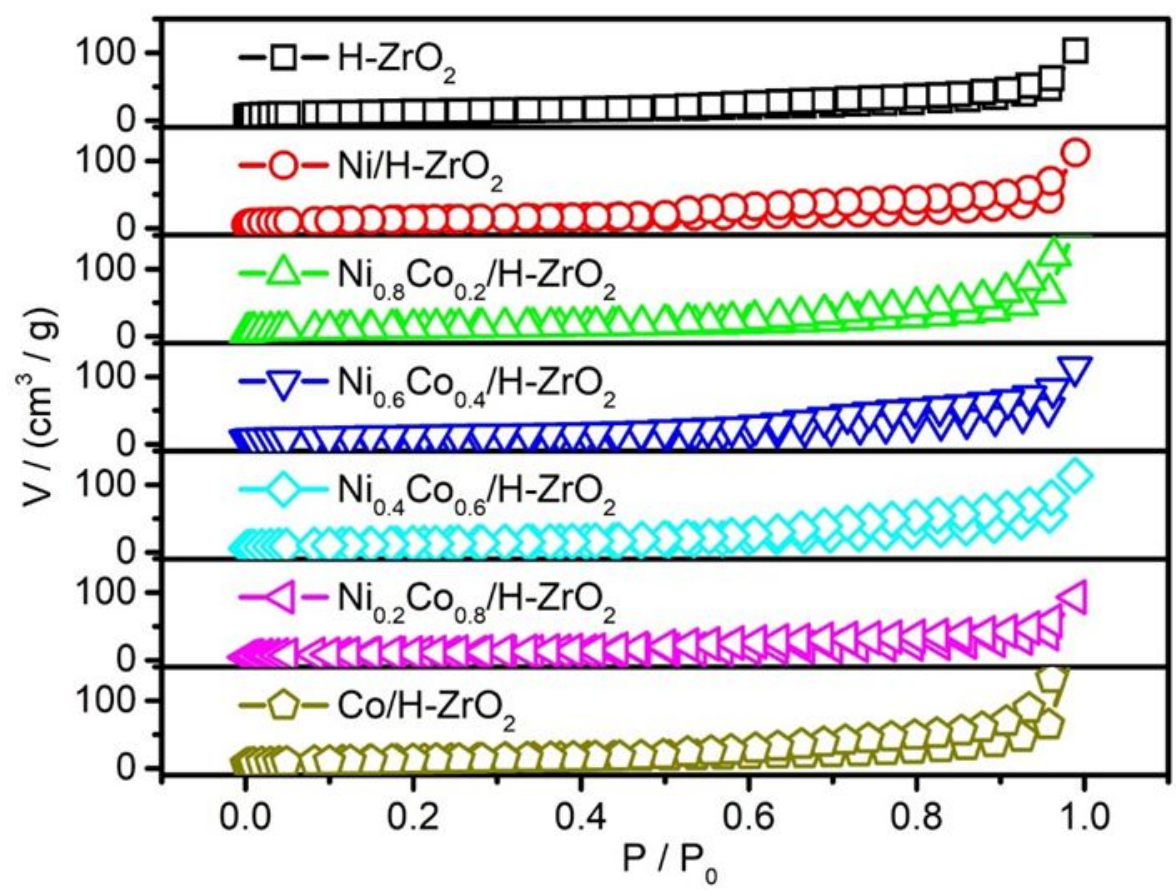

Figure S1. $\mathrm{N}_{2}$ adsorption-desorption isotherms of the as-reduced $\mathrm{Ni}_{\mathrm{x}} \mathrm{Co}_{\mathrm{y}} / \mathrm{H}-\mathrm{ZrO}_{2}$ catalysts. 
2. Effect of reaction temperature on the initial catalytic activity
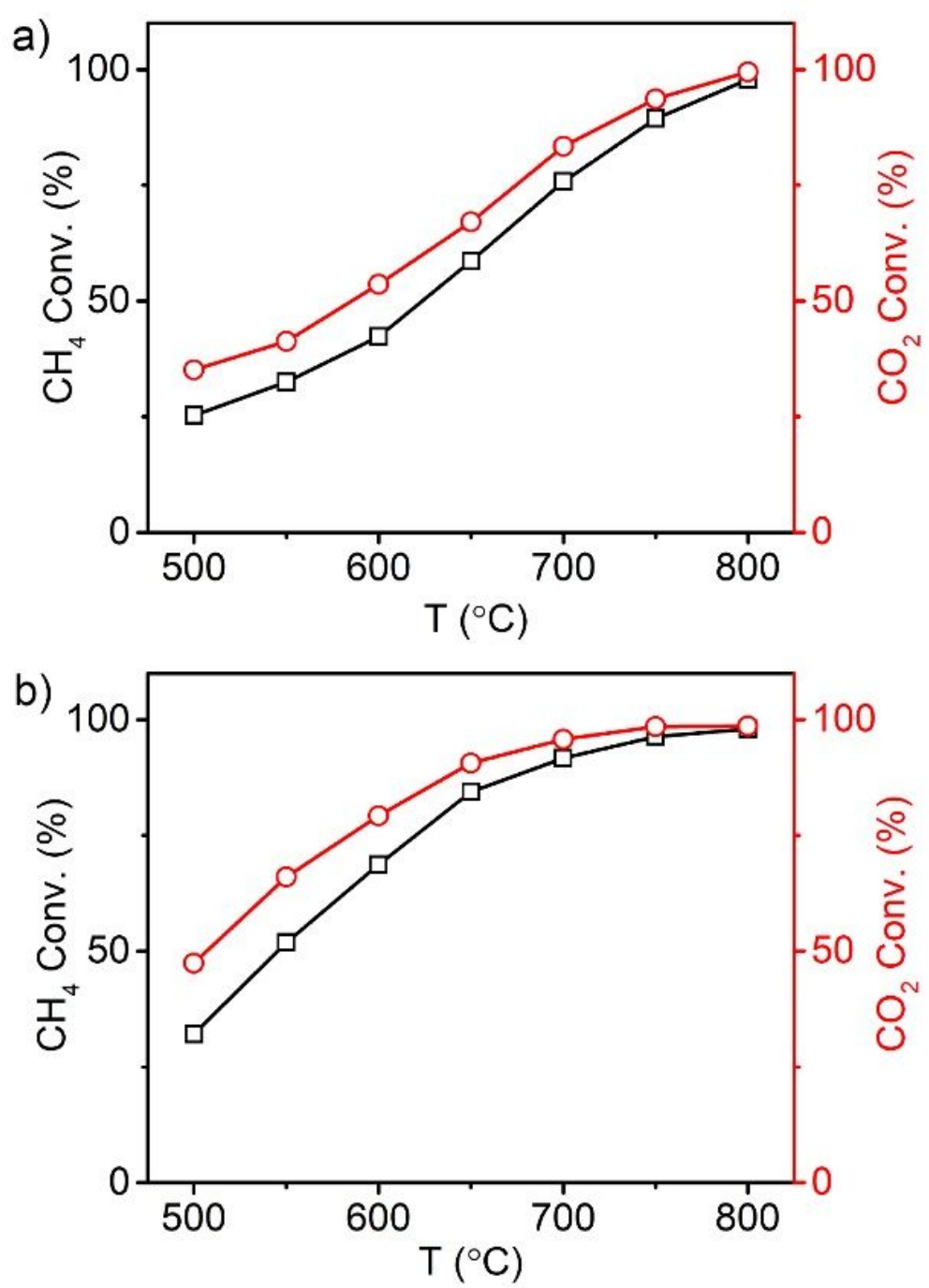

Figure S2. The effect of reaction temperature on the initial catalytic activity: (a) $\mathrm{Ni} / \mathrm{H}-\mathrm{ZrO}{ }_{2}$ and (b) $\mathrm{Ni}_{0.8} \mathrm{Co}_{0.2} / \mathrm{H}-\mathrm{ZrO}_{2}$ catalyst. 
3. $\mathrm{CO}_{2}$ TPD for $\mathrm{Ni} / \mathrm{H}-\mathrm{ZrO}_{2}$ and $\mathrm{Co} / \mathrm{H}-\mathrm{ZrO}_{2}$.

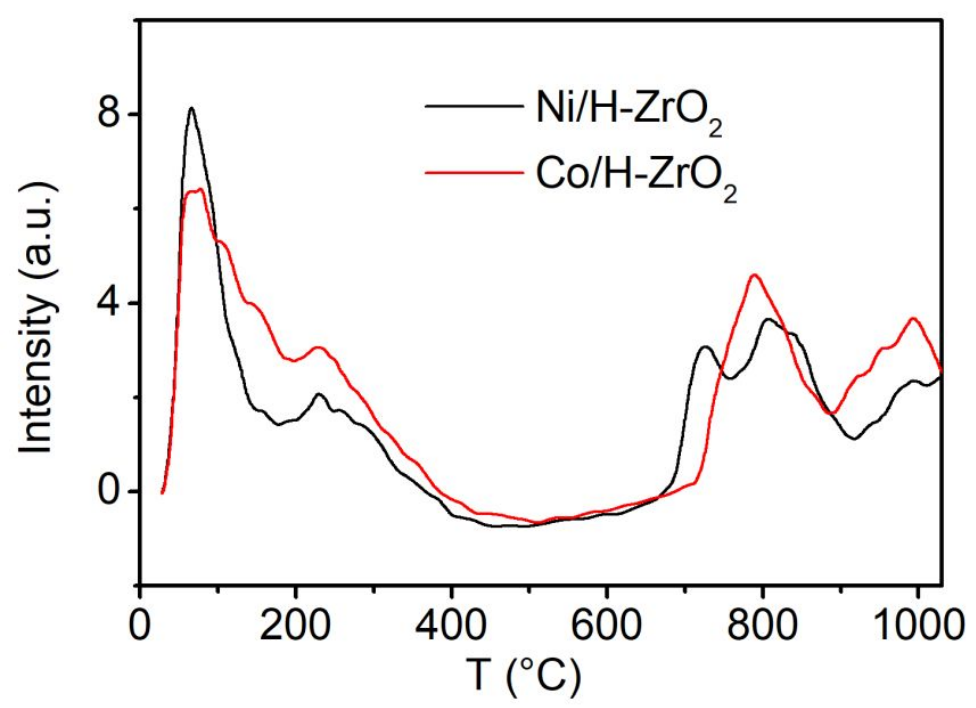

Figure S3. Temperature programmed desorption of $\mathrm{CO}_{2}$ pre-adsorbed on $\mathrm{Ni} / \mathrm{H}-\mathrm{ZrO}_{2}$ and $\mathrm{Co} / \mathrm{H}-\mathrm{ZrO}_{2}$ catalysts.

For TPD curve, a higher desorption temperature or a larger integral area under a desorption peak usually indicate a stronger interaction between the sample and the adsorbed gas. Since the adsorption of $\mathrm{CO}_{2}$ on metal is weaker than that on $\mathrm{ZrO}_{2}$, the former adsorption should be evaluated by the desorption curve below $400{ }^{\circ} \mathrm{C}$. It suggested that the $\mathrm{CO}_{2}$ has stronger interaction with $\mathrm{Co}$ as more $\mathrm{CO}_{2}$ was desorbed at $200-400{ }^{\circ} \mathrm{C}$. 
4. $\mathrm{XRD}$ patterns of $\mathrm{Ni} / \mathrm{H}-\mathrm{ZrO}_{2}$ and $\mathrm{Co} / \mathrm{H}-\mathrm{ZrO}_{2}$ after reaction for 24 hours.
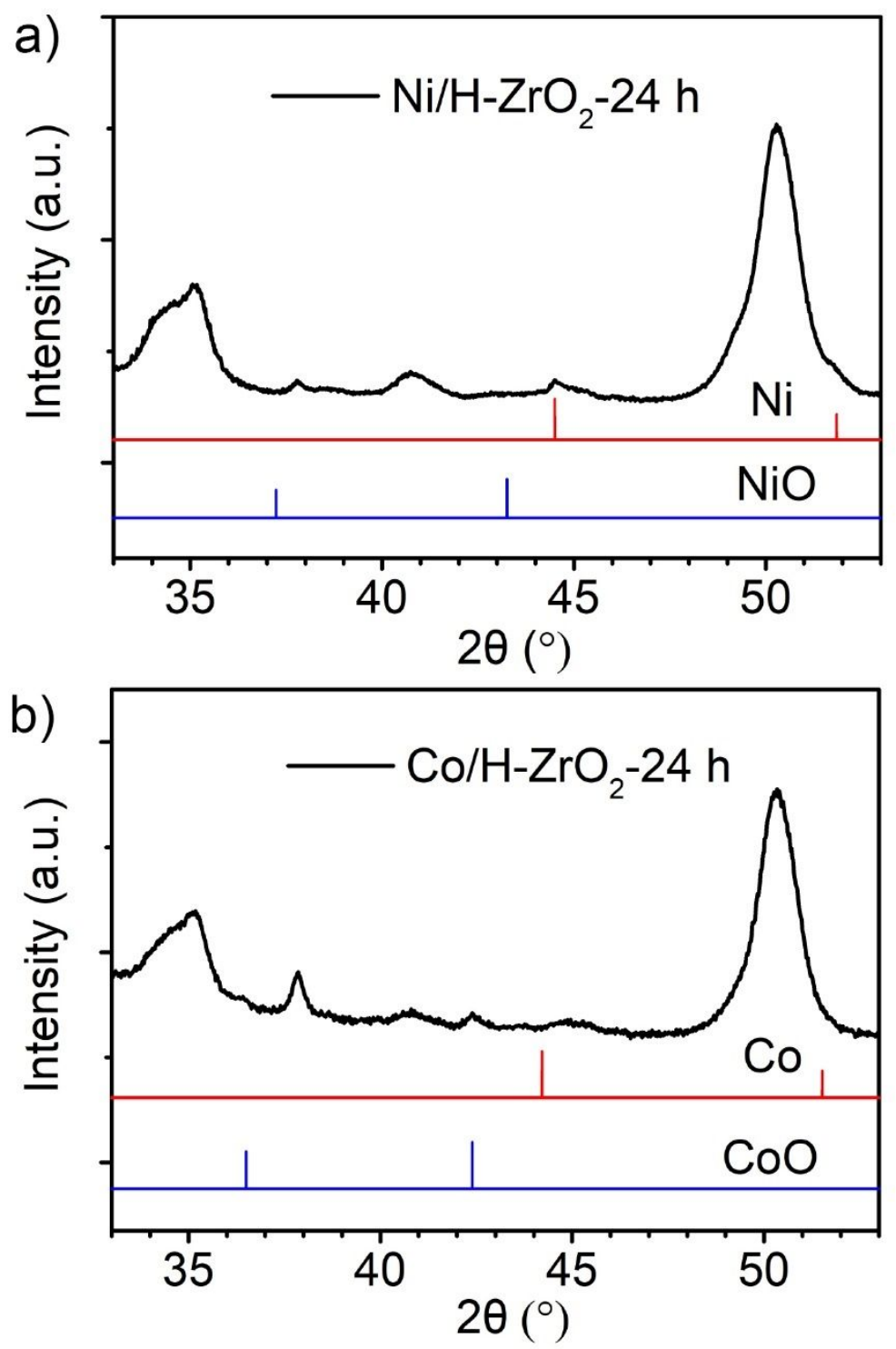

Figure S4. XRD patterns of $\mathrm{Ni} / \mathrm{H}-\mathrm{ZrO}_{2}$ and $\mathrm{Co} / \mathrm{H}-\mathrm{ZrO}_{2}$ after reaction for 24 hours. 

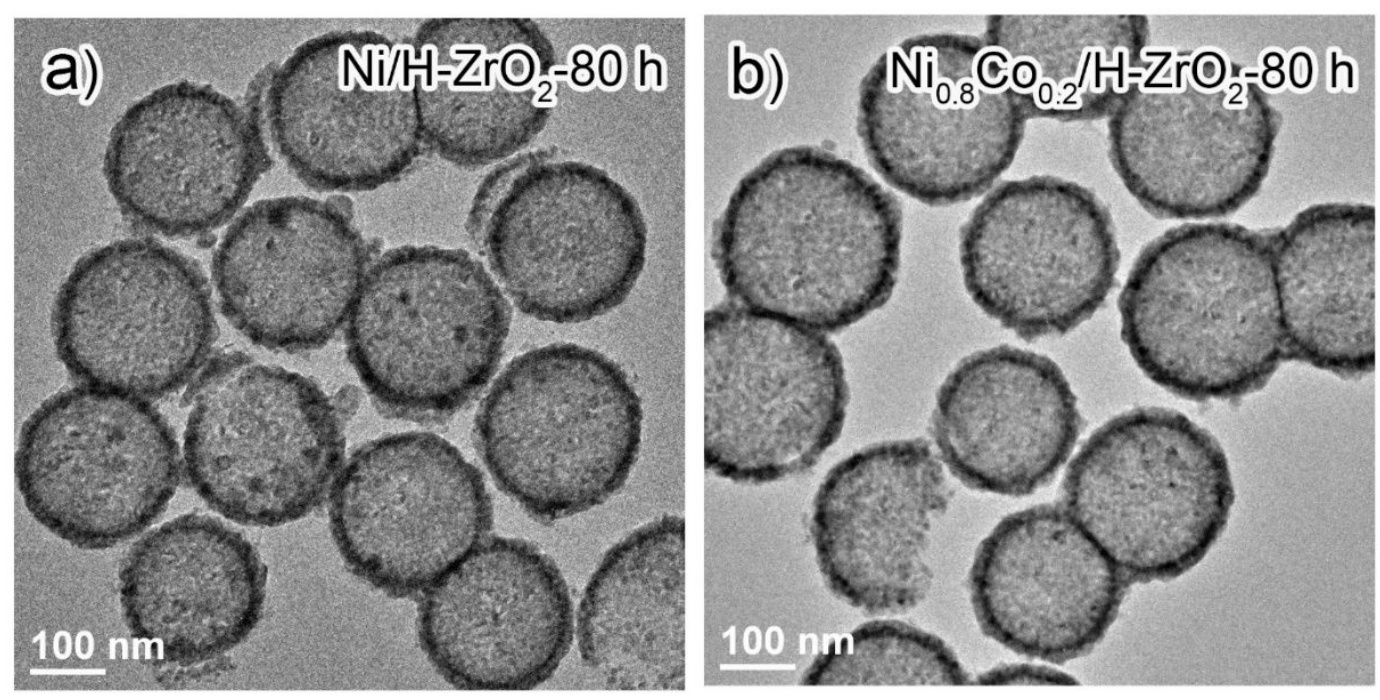

Figure S5. TEM images of $\mathrm{Ni} / \mathrm{H}-\mathrm{ZrO}_{2}$ and $\mathrm{Ni}_{0.8} \mathrm{Co}_{0.2} / \mathrm{H}-\mathrm{ZrO}_{2}$ catalysts after reaction for 80 hours.

\section{Atom concentration of the $\mathrm{Ni}_{0.8} \mathrm{Co}_{0.2} / \mathrm{H}-\mathrm{ZrO}_{2}$ catalyst from EDS analysis.}

Table S1. Atom concentration of the $\mathrm{Ni}_{0.8} \mathrm{Co}_{0.2} / \mathrm{H}-\mathrm{ZrO}_{2}$ catalyst from EDS analysis.

\begin{tabular}{cccc}
\hline Element & Weight $(\%)$ & Atomic $(\%)$ & Uncert. (\%) \\
\hline $\mathrm{O}(\mathrm{K})$ & 26.57 & 65.96 & 0.07 \\
$\mathrm{Si}(\mathrm{K})$ & 1.59 & 2.257 & 0.01 \\
$\mathrm{Co}(\mathrm{K})$ & $0.46 \dagger$ & 0.310 & 0.01 \\
$\mathrm{Ni}(\mathrm{K})$ & $1.85 \dagger$ & 1.252 & 0.01 \\
$\mathrm{Zr}(\mathrm{K})$ & 69.37 & 30.20 & 0.15 \\
\hline
\end{tabular}

$\dagger$ Theoretical weight percentage of $\mathrm{Ni}_{0.8} \mathrm{Co}_{0.2}$ alloy was $4.7 \%$ and the ICP-AES measurement also reported $4.72 \%$ for the alloy. However, EDS measurement indicated that the weight percentage of $\mathrm{Ni}_{0.8} \mathrm{Co}_{0.2}$ alloy was only $2.3 \%$. The negative error may be caused by the nonuniform loading of $\mathrm{Ni}_{0.8} \mathrm{Co}_{0.2}$ alloy on every $\mathrm{H}-\mathrm{ZrO}_{2}$ particles and the random selection of less loaded samples in EDS detection. The negative error may also be caused by the loss of $\mathrm{Ni}_{0.8} \mathrm{Co}_{0.2}$ alloy nanoparticles in preparation of TEM samples, where the $\mathrm{Ni}_{0.8} \mathrm{Co}_{0.2}$ nanoparticles with relatively weak interaction with 
the $\mathrm{H}-\mathrm{ZrO}_{2}$ particle may drop to the solution under sonication.

7. Comparison of TOF values of $\mathrm{CH}_{4}$ and $\mathrm{CO}_{2}$ catalyzed by Ni-based catalysts in literature and this work.

Table S2. Comparison of TOF values $\uparrow$ of $\mathrm{CH}_{4}$ and $\mathrm{CO}_{2}$ catalyzed by Ni-based catalysts in literature and this work.

\begin{tabular}{|c|c|c|c|c|}
\hline \multirow{2}{*}{$\begin{array}{l}\text { Ni-based } \\
\text { catalyst }\end{array}$} & \multirow{2}{*}{ Condition } & \multicolumn{2}{|c|}{ TOF $\left(s^{-1}\right)$} & \multirow{2}{*}{ Reference } \\
\hline & & $\mathrm{CH}_{4}$ & $\mathrm{CO}_{2}$ & \\
\hline \multirow{2}{*}{$\mathrm{Ni} / \mathrm{La}_{2} \mathrm{O}_{3}$} & $650^{\circ} \mathrm{C}$ & \multirow{2}{*}{0.024} & \multirow{2}{*}{0.027} & ACS Catal. \\
\hline & $12.5 \mathrm{~L} \cdot \mathrm{g}^{-1}$ cat. $^{-1}$ & & & $2016,6,4199-4205$ \\
\hline \multirow{2}{*}{$\mathrm{Ni} / \mathrm{Al}_{2} \mathrm{O}_{3}$} & $700^{\circ} \mathrm{C}$ & \multirow{2}{*}{0.402} & \multirow{2}{*}{0.376} & Chem. Commun., \\
\hline & $120 \mathrm{~L} \cdot \mathrm{g}^{-1}$ cat. $\mathrm{h}^{-1}$ & & & $2015,51,12044--12047$ \\
\hline \multirow{2}{*}{$\mathrm{Ni} / \mathrm{ZrO}_{2}$} & $750^{\circ} \mathrm{C}$ & \multirow{2}{*}{0.022} & \multirow{2}{*}{ / } & ACS Catal. \\
\hline & $15 \mathrm{~L} \cdot \mathrm{g}^{-1}$ cat. $\mathrm{h}^{-1}$ & & & $2011,1,82-88$ \\
\hline \multirow{2}{*}{ Ni/SBA-16 } & $750{ }^{\circ} \mathrm{C}$ & \multirow{2}{*}{0.157} & \multirow{2}{*}{0.168} & ACS Catal. \\
\hline & $15 \mathrm{~L} \cdot \mathrm{g}^{-1}$ cat. $\mathrm{h}^{-1}$ & & & $2013,3,1855-1864$ \\
\hline \multirow{2}{*}{ Ni/SBA-15 } & $750^{\circ} \mathrm{C}$ & \multirow{2}{*}{0.025} & \multirow{2}{*}{0.027} & Chem. Commun., \\
\hline & $3.75 \mathrm{~L} / \mathrm{g} \mathrm{h}$ & & & $2014,50,7250--7253$ \\
\hline \multirow{2}{*}{$\mathrm{Co} / \mathrm{Al}_{2} \mathrm{O}_{3}$} & $700{ }^{\circ} \mathrm{C}$ & \multirow{2}{*}{0.272} & \multirow{2}{*}{0.280} & Green Chem., \\
\hline & $11 \mathrm{~L} \cdot \mathrm{g}^{-1}$ cat. $\mathrm{h}^{-1}$ & & & $2014,16,885-896$ \\
\hline \multirow{3}{*}{$\mathrm{Ni} / \mathrm{CeO}_{2}$} & $700{ }^{\circ} \mathrm{C}$ & \multirow{3}{*}{0.063} & \multirow{3}{*}{0.071} & Applied Catalysis B: \\
\hline & & & & Environmental 165 (2015) \\
\hline & $4.9 \mathrm{~L} \cdot \mathrm{g}^{-1}$ cat. $\mathrm{h}^{-1}$ & & & $43-56$ \\
\hline \multirow{3}{*}{$\mathrm{Ni} @ \mathrm{SiO}_{2}$} & $700^{\circ} \mathrm{C}$ & \multirow{3}{*}{0.168} & \multirow{3}{*}{ / } & Applied Catalysis B: \\
\hline & $36 \mathrm{~L} \cdot \mathrm{g}^{-1} \mathrm{~h}^{-1}$ & & & Environmental 199 (2016) \\
\hline & S cat.11 & & & $155-165$ \\
\hline MgO-Doped & $850^{\circ} \mathrm{C}$ & \multirow{2}{*}{0.0092} & \multirow{2}{*}{0.0094} & Ind. Eng. Chem. Res. \\
\hline Ni/MAS-24 & $4 \mathrm{~L} \cdot \mathrm{g}^{-1}$ cat. $\mathrm{h}^{-1}$ & & & $2016,55,6931-6942$ \\
\hline
\end{tabular}




\begin{tabular}{|c|c|c|c|c|}
\hline $\mathrm{NiO}-\mathrm{CaO}-\mathrm{Al}_{2} \mathrm{O}_{3}$ & $\begin{array}{c}750{ }^{\circ} \mathrm{C} \\
30.3 \mathrm{~L} \cdot \mathrm{g}^{-1} \text { cat. }^{-1} \\
\end{array}$ & 0.34 & 0.353 & $\begin{array}{c}\text { ACS Catal. } \\
2012,2,1331-1342\end{array}$ \\
\hline $\mathrm{Ni}-\mathrm{Ce}-\mathrm{Al}$ Oxide & $\begin{array}{c}700{ }^{\circ} \mathrm{C} \\
18 \mathrm{~L} \cdot \mathrm{g}^{-1}{ }_{\text {cat. }} \mathrm{h}^{-1}\end{array}$ & 0.131 & 0.135 & $\begin{array}{c}\text { ACS Catal. } \\
2013,3,1638-1651\end{array}$ \\
\hline $\begin{array}{c}\mathrm{NiMgAl}- \\
\mathrm{LDH} @ \mathrm{~m}-\mathrm{SiO}_{2}\end{array}$ & $\begin{array}{c}750{ }^{\circ} \mathrm{C} \\
3.75 \mathrm{~L} \cdot \mathrm{g}^{-1} \text { cat. }^{-1}\end{array}$ & 0.028 & 0.029 & $\begin{array}{c}\text { Chem. Commun., } \\
\text { 2013, 49, 6770--6772 }\end{array}$ \\
\hline Ni-Pt@H-Silicalite-1 & $\begin{array}{c}800{ }^{\circ} \mathrm{C} \\
36 \mathrm{~L} \cdot \mathrm{g}^{-1} \text { cat. } \mathrm{h}^{-1}\end{array}$ & 0.948 & 0.998 & $\begin{array}{c}\text { J. Mater. Chem. A, } \\
2015,3,16461-16468\end{array}$ \\
\hline $\mathrm{CoNi} / \mathrm{Al}_{2} \mathrm{O}_{3}-\mathrm{CeZrO}_{2}$ & $\begin{array}{c}700{ }^{\circ} \mathrm{C} \\
6 \mathrm{~L} \cdot \mathrm{g}^{-1} \text { cat. } \mathrm{h}^{-1}\end{array}$ & 0.114 & 0.128 & $\begin{array}{l}\text { Ind. Eng. Chem. Res. } \\
\text { 2015, 54, 3775-3787 }\end{array}$ \\
\hline $\mathrm{NiCo}-\mathrm{CeZrO}_{2}$ & $\begin{array}{c}750{ }^{\circ} \mathrm{C} \\
30 \mathrm{~L} \cdot \mathrm{g}^{-1} \text { cat. } \mathrm{h}^{-1}\end{array}$ & 0.568 & 0.597 & $\begin{array}{c}\text { Applied Catalysis B: } \\
\text { Environmental } 206 \text { (2017) } \\
675-682\end{array}$ \\
\hline $\mathrm{Pt}-\mathrm{Ni} / \mathrm{Al}_{2} \mathrm{O}_{3}$ & $\begin{array}{c}700{ }^{\circ} \mathrm{C} \\
1.2 \mathrm{~L} \cdot \mathrm{g}^{-1}{ }_{\text {cat. }} \mathrm{h}^{-1}\end{array}$ & 0.006 & l & $\begin{array}{l}\text { Journal of Catalysis } 274(2010) \\
\qquad 11-20\end{array}$ \\
\hline $\mathrm{Ni}_{0.8} \mathrm{Co}_{0.2} / \mathrm{H}-\mathrm{ZrO}_{2}$ & $\begin{array}{c}700{ }^{\circ} \mathrm{C} \\
275 \mathrm{~L} \cdot \mathrm{g}^{-1}{ }_{\text {cat. }} \mathrm{h}^{-1}\end{array}$ & 0.358 & 0.359 & This work \\
\hline
\end{tabular}

$\dagger$ TOF values in literatures and this work were calculated by the molar amount of converted $\mathrm{CH}_{4} / \mathrm{CO}_{2}$ and that of $\mathrm{Ni}_{\mathrm{x}} \mathrm{Co}_{\mathrm{y}}$ alloy. The TOF were calculated according to the following formulas, where the molar amount of gas (n) were calculated from its initial flow rate and conversion, and the molar amount of $\mathrm{Ni}_{\mathrm{x}} \mathrm{Co}_{\mathrm{y}}$ alloy were calculated by the mass of catalyst, the weight percentage of $\mathrm{Ni}_{\mathrm{x}} \mathrm{Co}_{\mathrm{y}}$ alloy $(\mathrm{wt} \%)$ from ICP-AES and its molecular weight (M).

$$
\begin{gathered}
\left.\operatorname{TOF}\left(\mathrm{CH}_{4}\right)=\mathrm{n}\left(\mathrm{CH}_{4}\right) /\left[\mathrm{n}\left(\mathrm{Ni}_{\mathrm{x}} \mathrm{Co}_{\mathrm{y}}\right) \times \mathrm{t}\right)\right]=\left[\mathrm{r}\left(\mathrm{CH}_{4}\right)_{\text {in }} \times \mathrm{Conv} .\left(\mathrm{CH}_{4}\right) \times \mathrm{t} / 22.4\right] /[\mathrm{m}(\mathrm{cat}) \times \mathrm{wt} \% \\
\left.\left(\mathrm{Ni}_{\mathrm{x}} \mathrm{Co}_{\mathrm{y}}\right) / \mathrm{M}\left(\mathrm{Ni}_{\mathrm{x}} \mathrm{Co}_{\mathrm{y}}\right) \times \mathrm{t}\right] . \\
\left.\operatorname{TOF}\left(\mathrm{CO}_{2}\right)=\mathrm{n}\left(\mathrm{CO}_{2}\right) /\left[\mathrm{n}\left(\mathrm{Ni}_{\mathrm{x}} \mathrm{Co}_{\mathrm{y}}\right) \times \mathrm{t}\right)\right]=\left[\mathrm{r}\left(\mathrm{CO}_{2}\right)_{\text {in }} \times \mathrm{Conv} .\left(\mathrm{CO}_{2}\right) \times \mathrm{t} / 22.4\right] /[\mathrm{m}(\mathrm{cat}) \times \mathrm{wt} \% \\
\left.\left(\mathrm{Ni}_{\mathrm{x}} \mathrm{Co}_{\mathrm{y}}\right) / \mathrm{M}\left(\mathrm{Ni}_{\mathrm{x}} \mathrm{Co}_{\mathrm{y}}\right) \times \mathrm{t}\right] .
\end{gathered}
$$




\section{Comparison of $\mathrm{CH}_{4}$ and $\mathrm{CO}_{2}$ dissociative adsorption on pure and $\mathrm{Co}$-doped $\mathrm{Ni}(111)$ surface based on first-principles computation}

To investigate catalytic activity of $\mathrm{NiCo}$ bimetallic catalysts compared to pure $\mathrm{Ni}$, we have calculated the free energy barriers of dissociative chemical adsorption of $\mathrm{CH}_{4}$ and $\mathrm{CO}_{2}$ on pure and Co-doped Ni(111) surface based on first-principles density-functional theory (DFT). The Ni(111) surface is simulated by a $2 \times 2$ four-layer slab model with the bottom two layers fixed in all subsequent calculations. The NiCo bimetallic surface is modeled by replacing one fourth of Ni atoms in the top layer by $\mathrm{Co}$ atoms. When considering the adsorption and dissociation of $\mathrm{CH}_{4}$ and $\mathrm{CO}_{2}$ on $\mathrm{NiCo}$ surface, three possible sites (denoted as NiCo-I, II and III, respectively), as illustrated in Figure S6, are considered. The three cases differ in the position of doping $\mathrm{Co}$ atoms with respect to $\mathrm{CH}_{4}$ or $\mathrm{CO}_{2}$. For example, in NiCo-I, $\mathrm{CH}_{4}$ or $\mathrm{CO}_{2}$ dissociates in direct contact with $\mathrm{Co}$, while in NiCo-III, $\mathrm{CH}_{4}$ or $\mathrm{CO}_{2}$ dissociates on $\mathrm{Ni}$ atoms without direct contact to $\mathrm{Co}$ atoms. The adsorption energies $\mathrm{CH}_{4}$ and $\mathrm{CO}_{2}$ at different sites are collected in Table S3. The geometry of the most stable adsorption on the NiCo surface is illustrated in Figure S5. We characterize the catalytic activity of different surfaces by the free energy barrier, i.e. the free energy difference between the transition state and the reactant species $\left(X=\mathrm{CH}_{4}\right.$ or $\left.\mathrm{CO}_{2}\right)$ in the gas phase.

$$
\Delta G^{\ddagger}(X)=\Delta E^{\neq}+F_{X^{\ddagger}}^{(\text {vib) }}-F_{X}^{\text {(gas) }}
$$

where $\Delta E^{\neq}=E_{X^{\ddagger} \text {-surf }}-E_{X(\mathrm{gas})}-E_{\text {surf }}$ is the electronic energy barrier between the dissociative transition, $F_{X^{ \pm}}^{(\mathrm{vib})}$ is the vibrational free energy of the transition state, and $F_{X}^{(\text {gas })}=-R T \ln \left(Z_{\text {trans }} Z_{\text {rot }} Z_{\text {vib }}\right)$ is the free energy of $X$ in the gas phase including the contribution of translation, rotation and vibration. The free energy of the transition state is considered in the harmonic approximation, with all degrees of freedom except that along the reaction path treated as harmonic oscillators. The free energy of the reactant species in the gas phase is obtained in the ideal gas model. The rotation partition functions are calculated in terms of $Z_{\text {rot }}=\frac{T}{\sigma \theta_{\text {rot }}}$ (for linear molecules) or $Z_{\text {rot }}=\frac{1}{\sigma} \sqrt{\frac{\pi T^{3}}{\theta_{A} \theta_{B} \theta_{C}}}$ (for nonlinear functions), with the characteristic rotation temperatures taken from Ref. (1) for $\mathrm{CH}_{4}$ and $\mathrm{CO}_{2}$. We note that the contribution of the metal surface to the free energy is neglected under the assumption that the change of vibration of surface atoms due to the adsorption of reaction species is marginal. The python package TAMkin $^{2}$ was used for free energy calculations. 
All DFT calculations were performed by using the Vienna Ab initio Simulation Package (VASP) ${ }^{3}$, with the projected augmented wave (PAW) method to treat core-valence interaction, revised PerdewBurke-Ernzerhof (RPBE) ${ }^{4}$ generalized gradient approximation (GGA) in the spin-polarized formalism to treat exchange and correlation interactions. The kinetic cutoff energy for the planewave basis was set to $520 \mathrm{eV}$. The semi-empirical DFT-D3 method proposed by Grimme ${ }^{5}$ was exploited to overcome the difficulty of standard GGA in describing dispersion interaction. A $\Gamma$-centered $7 \times 7 \times 1 \mathrm{k}$-mesh was used to sample the Brillouin zone. Geometries were relaxed until the forces on all unconstrained atoms were less than $0.03 \mathrm{eV} / \AA$. To prevent the artificial electrostatic interactions between repeated slab images along the $z$-direction, all slab model calculations are performed with a dipole correction. A large box of $15 \times 15.5 \times 16 \AA$ were used for structural relaxation of gas phase species. Transition states were determined by using the climbing image nudged elastic band (CINEB) method ${ }^{6}$, sometimes combined with the dimer method ${ }^{7}$ for the cases in which CINEB had difficulty in achieving convergence. Vibrational frequencies were calculated to confirm the transition states, using a finite difference displacement of $0.015 \AA$.
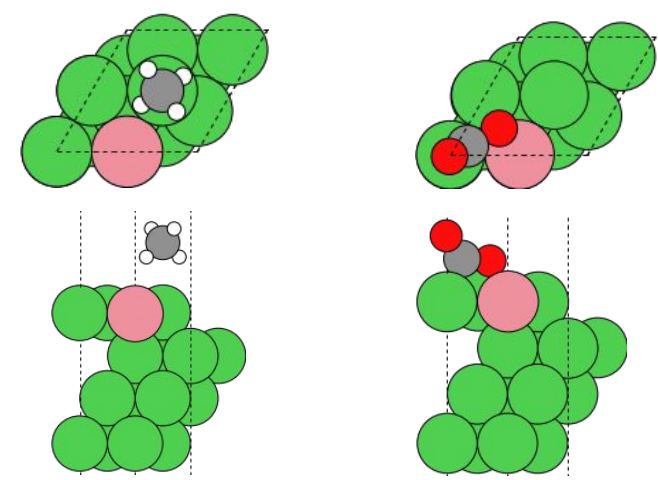

Figure S6. Top (upper) and side (lower) views of the most stable geometry for $\mathrm{CH}_{4}$ (left) and $\mathrm{CO}_{2}$ (right) adsorption on Co-doped $\mathrm{Ni}(111)$ surfaces (green for $\mathrm{Ni}$ and pink for $\mathrm{Co}$ ).

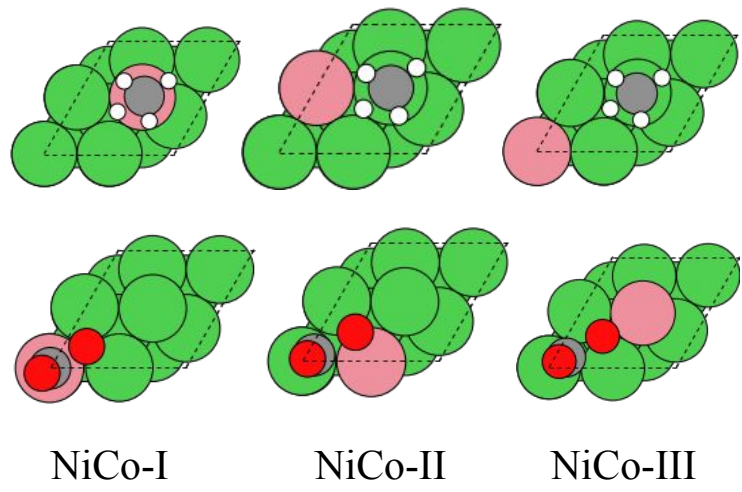

Figure S7. Illustration of transition state structures for $\mathrm{CH}_{4}$ (the upper panel) and $\mathrm{CO}_{2}$ (the 
lower panel) dissociation on Co-doped $\mathrm{Ni}(111)$ surfaces.

Table S3. Adsorption energies $\left(E_{\text {ads }}\right)$ and free energy barriers $\left(\Delta G^{\ddagger}\right)$ (in units of $\mathrm{kJ} / \mathrm{mol}$ ) for $\mathrm{CH}_{4}$ and $\mathrm{CO}_{2}$ dissociation reactions on pure and Co-doped $\mathrm{Ni}$ surfaces.

\begin{tabular}{ccccc}
\hline & $E_{\text {ads }}\left(\mathrm{CH}_{4}\right)$ & $E_{\text {ads }}\left(\mathrm{CO}_{2}\right)$ & $\Delta G^{\neq}\left(\mathrm{CH}_{4}\right)$ & $\Delta G^{\neq}\left(\mathrm{CO}_{2}\right)$ \\
\hline $\mathrm{Ni}$ & -25 & -42 & 166 & 167 \\
$\mathrm{NiCo}-\mathrm{I}$ & -25 & -37 & 197 & 150 \\
NiCo-II & -26 & -51 & 186 & 151 \\
NiCo-III & -23 & -37 & 206 & 175 \\
\hline
\end{tabular}

\section{References}

(1) Mcquarrie, D. A.; Simon, J. D. Physical Chemistry: A Molecular Approach. University Science Books (1997).

(2) Ghysels, A.; Verstraelen, T.; Hemelsoet, K.; Waroquier, M.; Van Speybroeck, V. TAMkin: a versatile package for vibrational analysis and chemical kinetics. J. Chem. Inf. Model. 2010, 50, 17361750.

(3) Kresse, G.; Furthmuller, J. Efficient iterative schemes for ab initio total-energy calculations using a plane-wave basis set. Phys. Rev. B 1996, 54, 11169-11186.

(4) Hammer, B.; Hansen, L.B.; Nørskov, J. K. Improved adsorption energetics within densityfunctional theory using revised Perdew-Burke-Ernzerhof functionals. Phys. Rev. B 1999, 59, 74137421.

(5) Grimme, S.; Antony, J.; Ehrlich, S.; Krieg, H. A consistent and accurate ab initio parametrization of density functional dispersion correction (DFT-D) for the 94 elements H-Pu. Chem. Phys. 2010, 132, 154104.

(6) Henkelman, G.; Uberuaga, B. P.; Jonsson, H. A climbing image nudged elastic band method for finding saddle points and minimum energy paths. J. Chem. Phys. 2000, 113, 9901-9904.

(7) Henkelman, G.; Jonsson, H. A dimer method for finding saddle points on high dimensional potential surfaces using only first derivatives. J. Chem. Phys. 1999, 111, 7010-7022. 